Portland State University

PDXScholar

\title{
Differentiation and Diffusion: Shifting Public Opinion Attitudes Toward Foreign Policy in North Africa
}

Lindsay J. Benstead

Portland State University, benstead@pdx.edu

Follow this and additional works at: https://pdxscholar.library.pdx.edu/polisci_fac

Part of the Political Science Commons

Let us know how access to this document benefits you.

\section{Citation Details}

Published as: Benstead, L. J. (2019). Differentiation and diffusion: shifting public opinion attitudes toward foreign policy in North Africa. Journal of North African Studies, 24(4), 618-639.

This Post-Print is brought to you for free and open access. It has been accepted for inclusion in Political Science Faculty Publications and Presentations by an authorized administrator of PDXScholar. Please contact us if we can make this document more accessible: pdxscholar@pdx.edu. 


\title{
Differentiation and diffusion: Shifting public opinion attitudes toward foreign policy in North Africa
}

Lindsay J. Benstead (benstead@pdx.edu), Associate Professor of Political Science, Mark O. Hatfield School of Government, Portland State University, Portland, OR, United States

\begin{abstract}
Drawing on Arab Barometer data, this article provides the backdrop for understanding continuity and change since the Arab Spring in national-level public opinion attitudes toward economic and political foreign policy issues in North Africa, inclusive of Algeria, Egypt, Libya, Morocco, and Tunisia. The article leverages the concepts of differentiation and diffusion to understand how international affairs shape public opinion in North Africa since the Arab Spring. Three findings emerge. First, public opinion about domestic and international issues are linked in the minds of North African citizens and foreign policy issues are more important factors underlying pre- and post-Arab Spring politics than are often recognized. Especially in the post-Arab Spring era, Arab citizens widely see external interference as a problem and this perception increased in every North African country between 2013 and 2016. Moreover, there is considerable variation across and within North African states in attitudes toward economic and political foreign policy issues, including the Arab-Israeli conflict and attitudes about economic and security relationships with Israel. Anti-Israeli sentiment increased substantially in the years leading up to and following the Arab Spring. Finally, since the Arab Spring, anti-Americanism, as measured by negative perceptions of U.S. culture, has declined in Algeria, Morocco, and Tunisia, but risen slightly in Egypt, even as North Africans demonstrate increased support for a U.S. role in resolving the Arab-Israeli conflict during this same time period. These trends suggest that anti-Americanism is highly dependent on specific domestic and international developments and is highly complex in the Arab world.
\end{abstract}

Keywords: public opinion, Arab Spring, foreign policy, Israeli-Palestinian conflict, antiAmericanism, Algeria, Egypt, Libya, Morocco, Tunisia, North Africa

Current Word Count: 5,938 (does not include figures and tables)

\section{Introduction}

Authoritarian regimes in North Africa prior to the Arab Spring left citizens with limited power to hold their governments accountable. This was especially true of foreign policy. Under authoritarianism, foreign policy is traditionally the purview of the executive; other state and nonstate actors, including the citizenry, have limited ability to hold the executive accountable (Fish 2006). Yet, the efforts of Arab governments to shape communication about foreign policy issues and the attempts of citizens to influence outside powers via protest and boycott movements 
illustrate the degree to which Arab citizens are concerned about external issues affecting their region (Benstead and Reif 2017; Farah and Newman 2010). Citizens throughout North Africa hold diverse views regarding foreign policy issues that affect their country (e.g., Benstead and Boduszynski 2015). At times, the views of citizens run counter to longstanding government policies. But, in ways that are under-recognised, North African views have evolved during the last decade as well, with support for recognizing Israel declining across the region and antiAmericanism diminishing on some measures as well. Exactly why views have shifted in some countries and not others, and how these changes relate to the Arab Spring, is not well understood.

Yet, to varying degrees across North African countries, the Arab Spring opened up new avenues for citizens to contest foreign policy. Nowhere is this truer than in Tunisia, which transitioned to an electoral democracy following the ousting of President Zine al-Abidine Ben Ali in 2011; newfound freedoms opened up the potential for public mobilisation on foreign policy issues, whether overt foreign policy issues like the Arab-Israeli conflict or indirect political issues like the domestic political economy. ${ }^{1}$ Indeed, more than is reflected in the international media, the Arab Spring mobilisations were, at least in part, related to the proWestern and pro-Israeli policies of authoritarian Arab regimes. The role that regional and international issues played in shaping the Arab Spring, and how its aftermath will ultimately reshape the region's foreign policy, is a new and crucial research area for students of international relations and comparative politics.

Drawing on Arab Barometer data, this article provides the backdrop for understanding continuity and change since the Arab Spring in national-level public opinion attitudes toward economic and political foreign policy issues. I focus on all five North African countries, 
inclusive of Algeria, Egypt, Libya, Morocco, and Tunisia. To understand the linkages between international and regional affairs and domestic public opinion, the article draws on the theoretical concepts of differentiation (the degree to which there is greater variation in public opinion across countries) and diffusion (the degree to which there is lesser variation in public opinion across countries) before and after the Arab Spring (Gourevitch 1978; Bush 2017). ${ }^{2}$

The remainder of this article proceeds as follows. After providing an overview of survey research in North Africa that deals with citizen attitudes toward foreign policy, I briefly explore three public opinion issues related to North African foreign policy: public perceptions of the Arab Spring and external interference in North Africa, Israel and the Arab-Israeli conflict, and perceptions of the West and especially the United States. A final section offers general conclusions.

\section{Citizen attitudes toward foreign policy in North Africa}

There is limited survey-based research on citizen attitudes toward foreign policy issues in North Africa (for exceptions, see Tessler and Warriner 1997; Zoubir and Aït-Hamadouche 2006;

Tessler, Jamal and Robbins 2012; Tessler and Robbins 2007; Blaydes and Linzer 2012; Benstead and Reif 2017). However, research using surveys of North African citizens is increasingly possible due to the rapid expansion of survey research in the Arab world, especially since the Arab Spring (see Table 1). Post-Arab Spring governments have allowed surveys to be conducted in several North African countries, including Tunisia and Libya, which were previously closed to survey researchers (Benstead 2017). ${ }^{3}$ As a result, there is a large body of publicly-available surveys from North Africa, including 10 datasets from the World Values Survey, 14 from the Arab Barometer, and 4 from Afro Barometer surveys.

[Table 1] 
The Arab Barometer focuses most directly on international and regional affairs and offers the largest number of questions that are consistent from wave to wave and across countries on these topics (Jamal and Tessler 2008; Tessler, Jamal, and Robbins 2012). In addition, survey research conducted by the Transitional Governance Project (TGP 2017), ${ }^{4}$ the Program on Governance and Local Development (GLD 2017), ${ }^{5}$ and other independent researchers has increased, most of which also focus on topics relevant to regional and international affairs (Bush and Jamal 2015; Bush and Prather 2017; Corstange and Marinov 2012). These data allow researchers to compare attitudes pre- and post-Arab Spring throughout North Africa, considering the fact that a total of six major surveys by these groups have been conducted in Libya, seven surveys have been conducted in Algeria and Morocco, and eight surveys have been conducted in Egypt and Tunisia. These data can help us better understand why international and regional developments shape public opinion of economic and political issues within and across countries.

The Arab Barometer in particular includes an extensive number of questions over various years that permit an examination of the competing views and conceptions of some of the most salient foreign policy issues in North Africa. As of this writing, a total of four "waves" of surveys have been carried out in North Africa, including in 2006 (Wave 1), 2011 (Wave 2), 2013-14 (Wave 3), and 2016 (Wave 4). By looking at data from 2006-2016, one can fully appreciate how public opinion forms the backdrop for understanding continuity and change in national-level foreign policy issues. In this regard, it is important to note that this article is not meant to be an exhaustive survey of the foreign policy content of all national surveys conducted in North Africa, nor is it even meant to be a systematic analysis of all foreign policy issues treated in the Arab Barometer. It instead provides a brief overview of three foreign issues captured in the Arab Barometer surveys, including public perceptions of the Arab Spring and 
external interference in Africa, public perceptions of relations with Israel and the Arab-Israeli conflict, and public perceptions of the role of the West, especially the United States. These issues provide the public opinion backdrop for understanding the evolving foreign policy roles played by the state and non-state actors explored in the other contributions to this special issue.

\section{Public perceptions of the Arab Spring and external interference in North Africa}

According to the first wave of the Arab Barometer that was conducted in Algeria and Morocco shortly before the Arab Spring (2006-2008), North African citizens identified a range of domestic problems as the most important issues facing their countries (see Table 2). The most important problem stated by respondents was their country's "economic situation," inclusive of poverty, unemployment, and inflation, which was mentioned by 56 percent of respondents in Morocco and 51 percent of respondents in Algeria. This was followed by "corruption," which was mentioned by 31 percent of respondents in Algeria and 27 percent of respondents in Morocco. Only 8 percent of Algerians and 4 percent of Moroccans mentioned "authoritarianism" as the most important problem confronting their country during the pre-Arab Spring. ${ }^{6}$ Very few citizens in Algeria and Morocco identified foreign policy issues as the most important challenges affecting their societies. As noted in Table 2, only 1 percent of Algerians and 1 percent of Moroccans cited "ending U.S. occupation in Iraq" as the most important challenge. Similarly, only 2 percent of Algerians and 2 percent of Moroccans cited the "Arab-Israeli conflict" as the most important challenge. In short, the Arab Spring was largely driven by perceptions of domestic as opposed to international issues.

[Table 2]

An emphasis on the overriding importance of the domestic dimension was reinforced by surveys carried out in Tunisia and Egypt in the immediate aftermath of the Arab Spring, in which 
few Tunisian and Egyptian citizens believed external issues played a role in causing the Arab Spring (see Table 3). When asked what they believed to be "the most important reason for the protests” that eventually toppled the Tunisian and Egyptian dictatorships, 54 percent of Egyptians and 63 percent of Tunisians cited "demands for improving the economic situation." The second most important reason was “combatting corruption,” which was cited by 29 percent of Egyptians and 44 percent of Tunisians. In sharp contrast, less than 1 percent of Egyptians and Tunisians cited external issues, whether their country’s “pro-Western policies” or "pro-Israeli policies.”

\section{[Table 3]}

Rising and increasingly negative perceptions of foreign influence nonetheless increased in several North African countries in the aftermath of the Arab Spring (see Figure 1). When asked in 2013 whether "internal factors" or "external factors” were "more important in causing the lack of development in the Arab world," significant but nonetheless variable numbers of North African citizens saw external factors as important, including 10 percent of Egyptians, 16 percent of Moroccans, 20 percent of Libyans and Tunisians, and 25 percent of Algerians. The data also demonstrate an important pattern over time. Three countries witnessed an increase from 2013 to 2016 in the number of citizens citing external factors as important (from 25 to 32 percent of Algerians, 20 to 35 percent of Tunisians, and 10 to 23 percent of Egyptians). Only in Morocco did this percentage decline, from 16 percent in 2013 to 13 percent in 2016. An Arab Barometer survey was not held in Libya in 2016.

\section{[Figure 1]}

Negative North African perceptions of foreign influence were particularly salient in response to the question as to whether respondents agreed "to some or a great extent" that 
"foreign interference" was "an obstacle to reform in your country" in the post-Arab Spring (see Figure 2). In 2016, those who agreed exceeded 70 percent in three North African countries: Algeria (76 percent), Tunisia (72 percent), and Egypt (72 percent). In the case of Libya, which was asked this question only in 2013 (a survey was not held in 2016), the percentage also exceeded 70 percent (77 percent were in agreement). Only in Morocco was this figure at a lower, but nonetheless relatively high level (49 percent in agreement). These results indicate strong North African public sentiment that their societies are less able to chart their own course against the tide of foreign interference. At the same time, however, the specific type of foreign interference (i.e., political or economic) or from where it emanates (i.e., the U.S., Europe, Russia, China, or the Gulf states, such as Saudi Arabia) is not specified in this question.

[Figure 2]

In sum, although North African citizens, like those throughout the world, focus first and foremost on their domestic environments as crucial to understanding their lot in life, including why the Arab spring occurred and what has unfolded in its aftermath, concluding on this basis that international issues are unimportant to North African citizens would be incorrect. Indeed, North African citizens are sophisticated in their views, with many perceiving foreign interference as a cause of the very economic and political problems at home that they say must be addressed.

\section{Public perceptions of relations with Israel and the Arab-Israeli conflict}

North African nations vary widely in their relations with Israel. Historically, Morocco, Tunisia, and Egypt have pursued relatively open relations with Israel, while Algeria and Libya have been more staunchly anti-Israeli. Officially, Morocco does not recognize Israel, but has long encouraged Israeli-Palestinian negotiations. The country has historically adhered to the Arab League's boycott of Israel, which began in 1945 (Benstead and Reif 2017), though Morocco 
began strengthening its economic ties with Israel in 1994 following the Oslo Accords. Morocco also strategically uses its support for the Israeli-Palestinian Peace Process to argue that western countries should accept its policy in the Sahara (Abadi 2007; Segev and Shumacher 2006). However, more formal efforts to promote bilateral trade were cut in 2000 following the second intifada, which began in 2000 (Fernández-Molina 2016).

Tunisia and Egypt have also had close foreign relations with Israel. Egypt established diplomatic relations with Israel following the 1979 Egyptian-Israeli Peace Treaty, which made Egypt a relative anomaly in the Middle East for its recognition of and diplomatic relations with Israel (Tessler 2009; Shama 2014). While it has never had official diplomatic relations with Israel, Tunisia became the first Arab country to host members of the Israeli leadership. Like Morocco, it cut trade relations with Israel in 2000 due to the outbreak of the second intifada. Unlike other countries in North Africa, however, Tunisia has had a more tangible relationship with the Palestinians, having hosted the Palestinian Liberation Organisation (PLO) leadership in Tunis from 1982 until the Oslo Accords were signed in 1993 (Abadi 2017).

Algeria and Libya have taken a more stringent approach toward Israel (Joffe and Paoletti 2011; St John 2003, 2011). Opposition to Israel on the part of both the Algerian government, as well as its population, has always been strong. Algeria's own troubled history with colonialism informs much of the public's opposition to Israeli policy. Algeria fought a brutal revolutionary war against France from 1954 to 1962, and ever since has been a leader in the anti-colonial and non-aligned movement (Mortimer 2015). Libya too did not had diplomatic relations with Israel. Muammar Qaddafi frequently spoke out about Israeli colonialism and interference in Palestine and Africa, which he saw as sapping Arab unity and strength (St John 2011). Yet, in the regime's final months, Saif al-Islam Qaddaffi unsuccessfully conducted back channel diplomacy with 
Israel, via a Jewish Austrian friend and political party member, David Lazar, and an Israeli Druze member of the Knesset, Ayoob Kara, seeking to end NATO airstrikes against Libya in exchange for assistance securing the release of Gilad Shalit from HAMAS (Asharq Al-Awsat 2011). On August 23, 2011, two months before the capture and death of Muammar Qaddafi, Ahmed Shabani, a member of the Libyan opposition, expressed support for a two-state solution in an attempt to build international support for the transitional regime in Libya (Melman 2011). Later that year, Israel voted in the United Nations General Assembly to recognize the National Transition Council as the representative of the Libyan people (United Nations 2011).

When it comes to the Arab-Israeli conflict, North Africans overwhelmingly express solidarity with the Palestinians. Attitudes about the Arab-Israeli peace process and economic and security relationships with Israel have nonetheless shifted over time (see Figure 3). In general, Algerians hold the least conciliatory view toward Israel, while Egyptians hold the most conciliatory view. In 2011, for example, when North Africans were asked whether the "Arab world should accept the existence of Israel as a Jewish state in the Middle East,” 35 percent of Egyptians (the most conciliatory) and 5 percent of Algerians (the least conciliatory) stated that they would accept Israel, but only if a two-state solution was reached. The views of Tunisians (18 percent) and Moroccans (24 percent) were between these extremes (and Libyans were not surveyed in 2011).

[Figure 3]

Support for recognising Israel, even if a two-state solution with the Palestinians is reached, has declined throughout North Africa over the last decade, except in the case of Algeria, which witnessed a slight increase from 5 percent in 2011 to 11 percent in 2013. This diffusion effect can likely be attributed to deteriorating relations between the Israelis and the Palestinians 
since the first intifada, including the breakdown of the Oslo Peace Process and the policies of separation that gave rise to the increasing cycle of violence between the two communities (Gordon 2008). In some cases (i.e., Morocco), this decline spans the pre- to post-Arab Spring period, while in others (i.e., Tunisia, Libya, and Egypt), data are only available in the post-Arab Spring period. The decline is quite substantial in some countries. In Egypt, which had the most conciliatory position toward Israel, support for Israel even if a two-state solution is reached dropped from 35 percent in 2011 to 19 percent in 2013. After Egypt, the country with the highest support for recognising Israel was Morocco in 2006, when it stood at 32 percent. However, by 2011, Moroccan support fell to 24 percent. In Tunisia, support fell from 18 percent in 2011 to 13 percent in 2013. The survey was conducted one time in Libya in 2011, when only 11 percent agreed with recognising Israel. These trends, at least in the cases of Egypt, Morocco, and Tunisia, are perhaps partially attributable to the rise to positions of power of Islamist parties in each of these countries (see Quinn Mecham's contribution in this special issue).

[Figure 3]

The fourth wave of the Arab Barometer, conducted in 2016, obtained higher support for recognising Israel, but the question was worded differently from that used in earlier years: "Do you support or oppose the solution to the Arab-Israeli conflict based on the establishment of a Palestinian State alongside Israel known as the two-state solution?” (see Figure 4). The percentage of respondents "supporting” this solution included 25 percent of Algerians, 38 percent of Moroccans, 46 percent of Egyptians, and 64 percent of Tunisians (the $4^{\text {th }}$ wave of the Arab Barometer was not carried out in Libya). Although the difference between the 2016 survey responses and those of previous years is potentially due to different wording, one must also 
consider the possibility that public opinion has shifted more in favor of Israel in the post-Arab Spring era.

\section{[Figure 4]}

At least (and only) in the case of Egypt, another means of determining North African support for relations with Israel during the Arab spring involved asking in 2011 and 2013 whether Egyptians supported "maintaining” their country’s peace treaty with Israel (see Figure 5). In 2011, 44 percent "strongly" supported maintaining the treaty, while 30 percent supported maintaining, 7 percent did not support, and 15 percent strongly did not support. By 2013, only 25 percent of Egyptians strongly supported maintaining the treaty, while 45 percent supported maintaining, 8 percent did not support, and 10 percent strongly did not support. Although these results, if we combine "strongly supported" and "supported," show some decline in support for maintaining the status quo with Israel (from a total of 74 percent in 2011 to 70 percent in 2013), overall a strong majority of Egyptians still favoured maintaining the treaty two years after the Arab Spring uprisings. This was the case even following the ousting of Hosni Mubarak in 2011 and new elections that resulted in an electoral majority for Islamist parties in both chambers of parliament in 2011-2012, as well as the election in 2012 of Mohammed Morsi, the presidential candidate of the Muslim Brotherhood.

[Figure 5]

A final means for understanding North African support for relations with Israel during the Arab Spring involved asking in 2013 questions about economic and security relations with Israel. As for the economic dimension, 56 percent of Egyptians, 58 percent of Moroccans, and 82 percent of Tunisians indicated a preference for decreasing economic ties with Israel (see Figure 6). Algeria constituted the exception; only 20 percent of Algerians indicated a preference for 
decreased economic ties, whereas 1 percent favored increased ties and 71 percent favored maintaining existing ties. A survey was not carried out in Libya. A similar dynamic emerged regarding security ties: 51 percent of Egyptians, 54 percent of Moroccans, and 81 percent of Tunisians indicated a preference for decreasing security ties with Israel (see Figure 7). Algeria once again constituted the only exception; only 21 percent of Algerians indicated a preference for decreased security ties, whereas 1 percent favored increased ties and 69 percent favored maintaining existing ties. A survey was not carried out in Libya. Once again, these trends, at least in the cases of Egypt, Morocco, and Tunisia, are perhaps partially attributable to the rise to positions of power of Islamist parties in each of these countries (see Quinn Mecham’s contribution in this special issue).

[Figure 6 and Figure 7]

\section{Public perceptions of the role of the West, especially the United States}

While there is some variation in North African foreign relations with the West, especially the United States, all can generally be described as pragmatic - or what Mortimer (2015) refers to as national interest pragmatism - particularly during the Arab Spring years. Much of this pragmatism is shaped by joint security goals (Gause 2003/2004, 2015; Ryan 2009). Indeed, North African states cooperate closely with the U.S. on security matters, and security interdependence between the U.S. and many Arab states has increased in the post-cold war period (Jamal 2012; see also the article by Schumacher and Schraeder in this special issue). Egypt receives substantial U.S. military aid as a result of the Egyptian-Israeli Peace Treaty, which was brokered by the U.S. during the Carter administration. Algeria, Morocco, and Tunisia are allies in the Global War on Terror (Fernández-Molina 2016; Benstead and Reif 2017), and since 2013 Tunisia has enjoyed non-NATO ally status (Benstead 2016). Under Qaddafi, Libya 
and the U.S. had conflictual relations, which led to military skirmishes and U.S. sanctions being imposed on Libya beginning in the 1980s (St. John 2011). The U.S. was the largest partner in NATO to impose the no-fly zone that allowed rebels in 2011 to overthrow Qaddafi, leaving Libyans with strongly pro-American and pro-western sentiments after 2012 (Benstead and Boduszynski 2015). ${ }^{4}$

North Africans vary in their views of U.S. and Western culture, with positive views more common than is recognised in the Western media. This is clearly demonstrated by Waves 1-4 of the Arab Barometer which asked the question, "Do you agree or disagree with the following statement: American and Western culture have positive aspects?” (see Figure 8). Before the Arab Spring, there was much more diversity (and fluidity) in reported attitudes toward American culture. Yet, with the exception of Egypt, the post-Arab Spring period saw a decline in antiAmericanism, as measured by positive orientations toward U.S. culture. In Morocco, for example, agreement that U.S. culture has positive aspects rose from 60 percent in 2006 to 74 percent in 2016, while in Algeria, it increased from 52 percent in 2006 to 71 percent in 2016, with an intervening drop to 37 percent in 2013. In Tunisia, positive impressions increased from 61 percent in 2011 to 77 percent in 2016, while in Egypt, it declined slightly from 53 percent to 48 percent between 2011 and 2016.

[Figure 8]

One way of more precisely understanding North African perceptions of the U.S. is to ask about specific U.S. policies toward the Arab world. Specifically, Waves 3-4 of the Arab Barometer asked the question, "What is the most positive policy that the U.S. can follow in our region?” (see Table 4). It is striking that the preferred policy across all five North African countries in 2013-14 was one of U.S. non-interference within the Arab world (i.e., "The U.S. 
shouldn’t interfere”). This ranged from as low of 26 percent of Moroccans to 79 percent of Algerians. Moreover, these perceptions changed from 2013 to 2016. In Egypt and Morocco, for example, greater numbers of respondents called for U.S. non-interference (31 percent of Moroccans and 62 percent of Egyptians). In Algeria and Tunisia, however, decreasing numbers of respondents called for U.S. non-interference, thereby suggesting a desire - at least in these two countries - for a greater U.S. role within the region. Nevertheless, the opinion that the U.S. should not intervene at all was by far the most popular answer among several important foreign policy-related responses, including should the U.S. intervene to promote democracy, promote economic development, promote women’s rights, or contain Iran.

One of the most interesting shifts, however, involved the specific policy response as to whether the U.S. should attempt to "solve the Arab-Israeli conflict" (see Table 4). There was increasing support throughout North Africa from 2013 to 2016 for the U.S. to take on a more proactive role in this regard. The proportion supporting this policy increased from 7 to 23 percent in Algeria. In Egypt, it remained constant at 15 percent, while in Morocco it increased from 20 to 27 percent. In Tunisia, the increase was from 7 to 19 percent. This suggests that while sentiments among North Africans toward Israel have soured over the course of a decade, this has brought with it an increased demand for Western countries to assist with a resolution to the conflict.

\section{[Table 4]}

Finally, it is also striking to note the degree to which North African publics are willing to justify attacks against the United States (e.g., see Tessler and Robbins 2007). This is clearly demonstrated by a question, which asked whether North African publics agreed or disagreed with the following statement: 'The United States' interference in the region [Arab world] justifies armed operations against the United States everywhere” (see Figure 9). Whereas support 
for militancy increased from 40 percent to 61 percent in Algeria between 2011 and 2013, it nonetheless declined in Tunisia from 44 percent to 34 percent during those same years. In Morocco and Libya, the question has been asked just once, but a larger proportion of Moroccans (49 percent) than Libyans (37 percent) saw these actions as at least somewhat justified (Tessler and Robbins 2007).

[Figure 9]

\section{Conclusion}

These analyses illustrate the linkages between international and regional affairs and domestic public opinion and offer examples of public opinion differentiation (the degree to which there is greater variation in public opinion across countries) and diffusion (the degree to which there is lesser variation in public opinion across countries) before and after the Arab Spring (Gourevitch 1978; Bush 2017). Three findings emerge. First, public opinion about domestic and international issues are linked in the minds of North African citizens, and foreign policy issues, broadly construed, are more important factors underlying the pre- and post-Arab Spring than are often

recognized by analyses that emphasize domestic issues (Brownlee, Masoud, and Reynolds 2015). Especially in the post-Arab Spring era, Arab citizens widely see external interference as a problem, and this perception increased in every North African country between 2013 and 2016. Second, there is considerable variation across and within North African states in attitudes toward economic and political foreign policy issues, including the Arab-Israeli conflict and attitudes about economic and security relationships with Israel. Anti-Israeli sentiment increased substantially in the years leading up to and following the Arab Spring, which also coincided with the second intifada. Finally, since the Arab Spring, anti-Americanism, as measured by negative perceptions of U.S. culture, has declined in Algeria, Morocco, and Tunisia, but risen slightly in 
Egypt, even as North Africans demonstrate increased support for a U.S. role in resolving the Arab-Israeli conflict during this same time period. These trends suggest that anti-Americanism is highly dependent on specific domestic and international developments, and in any case is highly complex, especially in the Arab world (Lynch 2006; Benstead and Reif 2005, 2013; Zoubir and Ait-Hamadouche 2006). In sum, analyzing the continuity and change in national-level attitudes toward economic and political foreign policy issues in North Africa help inform our understanding of both the nuance of public opinion across North Africa, as well as how public opinion shaped the foundations and outcomes of the Arab Spring.

\section{Notes}

${ }^{1}$ Libya too held a free and fair election in 2012, but the security vacuum and intensification of civil war has undercut representative government.

${ }^{2}$ In classic international relations theory, Waltz $(1959,1975)$ explained war through three images of analysis: the individual, the state, and the international system (i.e., anarchy).

Gourevitch (1978) expanded on this work by arguing that domestic political structures and outcomes are shaped by the international system, in contrast to the second image, which explores the ways that international politics are shaped by characteristics of the state, such as capitalism. (Bush 2017; see also Bamert, Gilardi, and Wasserfallen 2015; Lynch 2013; Solingen 2012; Bush and Prather 2017; Benstead, Kao, and Lust 2017; Corstange and Marinov 2012; Marinov 2013; Bush and Jamal 2015).

${ }^{3}$ Due to authoritarianism, none of the major cross-national surveys were conducted before 2011 in Tunisia and Libya. In Egypt, the World Values Survey was conducted in 2001 and 2008, but the Arab Barometer, with its direct relevance to the study of public attitudes toward foreign policy, was not conducted in Egypt until after the Arab Spring. 
${ }^{4}$ Ellen Lust, Lindsay Benstead, and collaborators launched the TGP (2017) to study the transitional politics of Tunisia, Libya, and Egypt.

5 The Local Governance Performance Index was developed by Benstead, Landry, Lust, and Malouche to explain variation in education, health, and municipal service quality and transparency. The survey draws large samples of 300 more in each locality, allowing comparisons to be made across municipalities (GLD 2017).

${ }^{6}$ Data weighted for all analyses of Waves 2 and 3 of the Arab Barometer.

\section{References}

Abadi, Jacob. 2007. “The Road to the Israeli-Moroccan Rapprochement.” Journal of North African Studies 5(1): 27-54.

Abadi, Jacob. 2017. “Tunisia and Israel: Relations under Stress.” Middle Eastern Studies 53(4): 507-532.

Arab Barometer. 2017. “Arab Barometer Home Page.” accessed November 2017. http://www.arabbarometer.org/.

Asharq Al-Awsat. (2011). "Gaddafi offered to Handover Shalit in Exchange for Halting NATO Attack - Israeli Official.” https:/eng-archive.aawsat.com/theaawsat/news-middleeast/gaddafi-offered-to-handover-shalit-in-exchange-for-halting-nato-attack-israeliofficial 2 September, 2011. (Accessed March 13, 2018).

Bamert, Justus, Fabrizio Gilardi, and Fabio Wasserfallen. 2015. 'Learning and the Diffusion of Regime contention in the Arab Spring." Research \& Politics 2(3): 1-9.

Beinin, Joel, and Lisa Hajjar. 2016. "Primer on Palestine, Israel, and the Arab-Israeli Conflict.” Middle East Research and Information Project. http://www.merip.org/primer-palestineisrael-arab-israeli-conflict-new. 
Benstead, Lindsay J. 2016. "Tunisia." in The Government and Politics of the Middle East and North Africa, 8th Ed, edited by Mark Gasiorowski and Sean Yom, 463-90. Boulder: Westview Press.

Benstead, Lindsay J. 2017. "Survey Research in the Arab World.” In Oxford University Press Handbook on Polling and Polling Methods, edited by Lonna Atkeson and R. Michael Alvarez. New York: Oxford University Press.

Benstead, Lindsay J., and Mietek Boduszynski. 2015. “Encouraging Democracy after the Arab Spring: Public Opinion and the Potential for Linkages." Memo prepared for the American Institute for Maghreb Studies, workshop on "Linking Public Opinion and Political Action.” Tunis.

Benstead, Lindsay J., and Megan Reif. 2005. 'Hearts, Minds, and Pocketbooks: AntiAmericanisms and the Politics of Consumption in the Muslim World.” Paper Presented at the Annual Meeting of the Middle East Studies Association, Washington, DC. November 18-22, 2005.

Benstead, Lindsay J., and Megan Reif. 2013. "Polarization or Pluralism? Language, Identity, and Attitudes toward Western Culture among Algeria’s Youth.” Middle East Journal of Culture and Communication 6(1): 75-106.

Benstead, Lindsay J., and Megan Reif. 2017. “Coke, Pepsi or Mecca Cola? Why Product Characteristics Shape Collective Action Problems and Boycott Success.” Politics, Groups, and Identities 5(2): 220-241.

Benstead, Lindsay J., Kristen Kao, and Ellen Lust. 'Why does it Matter What Monitors Say? The Impact of Election Monitors on Legitimacy.” Paper presented at the International Political Science Association meeting, Baltimore MD, February 22-25, 2017. 
Benstead, Lindsay J., and Ethan Snyder. 2016. "Is Security at Odds with Democracy? Evidence from the Arab World.” Paper presented November 4, 2016, North African Studies Workshop, Oregon State University, Corvallis, OR.

Blaydes, Lisa and Drew A. Linzer. 2012. "Elite Competition, Religiosity, and Anti-Americanism in the Islamic World.” American Political Science Review 106(2): 225-243.

Brownlee, Jason, Tarek Masoud, and Andrew Reynolds. 2015. The Arab Spring: Pathways of Repression and Reform. New York: Oxford University Press.

Bush, Sarah Sunn. 2011. "International Politics and the Spread of Quotas for Women in Legislatures.” International Organization 65(1): 103-37.

Bush, Sarah Sunn. 2017. "Varieties of International Influence and the Middle East.” PS: Political Science \& Politics 50(3): 668-71.

Bush, Sarah Sunn and Amaney A. Jamal. 2015. "Anti-Americanism, Authoritarian Politics, and Attitudes about Women's Representation: Evidence from a Survey Experiment in Jordan." International Studies Quarterly 59(1): 34-45.

Bush, Sarah Sunn and Laura Prather. 2017. "The Promise and Limits of Election Observers in Building Election Credibility." The Journal of Politics 79(3): 921-935.

Corstange, Daniel. 2016. "Anti-American Behavior in the Middle East: Evidence from a Field Experiment in Lebanon." Journal of Politics 78(1): 311-325.

Corstange, Daniel and Nikolay Marinov. 2012. 'Taking Sides in Other People’s Elections: The Polarizing Effect of Foreign Intervention." American Journal of Political Science 56(3): 655-670.

Farah, Maya F., and Andrew J. Newman. 2010. “Exploring Consumer Boycott Intelligence Using a Socio-Cognitive Approach.” Journal of Business Research 63(4): 347-355. 
Fernández-Molina, Irene. 2016. Moroccan Foreign Policy under Mohammed VI, 1999-2014. New York: Routledge.

Fish, Steven M. 2006. "Creative Constitutions: How Do Parliamentary Powers Shape the Electoral Arena?” In Electoral Authoritarianism: The Dynamics of Unfree Competition, edited by Andreas Schedler, 181-97. Boulder: Lynne Rienner Publishers.

Gause, F. Gregory, III (2003/4). "Balancing What? Threat Perception and Alliance Choice in the Gulf.” Security Studies 13(2): 273-305

Gause, F. Gregory, III. 2015. “Ideologies, Alliances and Underbalancing in the New Middle East Cold War.” Memo prepared for the International Relations and a new Middle East symposium, Project on Middle East Political Science.

Ghiles-Meilhac, Samuel. 2014. 'Tunisia's Relations with Israel in a Comparative Approach: The Case of the Debate on Normalisation during the Arab Awakening." Bulletin du Centre de recherche français à Jérusalem 25: 1-11.

Gordon, Neve. 2008. Israel's Occupation. Berkeley : University of California Press.

Gourevitch, Peter. 1978 "The Second Image Reversed: The International Sources of Domestic Politics." International Organization 32(4): 881-912.

Jamal, Amaney A. 2012. Of Empires and Citizens: Pro-American Democracy or No Democracy at All? Princeton: Princeton University Press.

Jamal, Amaney A., and Helen V. Milner. 2017. 'Do Economic Interests Transcend SocioCultural Values? Understanding Support for Globalization in MENA.” Working Paper.

Jamal, Amaney A. and Mark A. Tessler. 2008. "Attitudes in the Arab World." Journal of Democracy 19(1): 97-110. 
Jiang, Junyan and Dali L. Yang. 2016. "Lying or Believing? Measuring Preference Falsification from a Political Purge in China." Comparative Political Studies 49(5): 600-634.

Joffé, George \& Emanuela Paoletti. 2011. "The Foreign Policy Process in Libya." The Journal of North African Studies 16(2): 183-213.

Katzenstein, Peter J. and Robert O. Keohane. 2006. Anti-Americanisms in World Politics. New York: Cornell University Press.

Kalinin, Kirill. 2016. "The Social Desirability Bias in Autocrat's Electoral Ratings: Evidence from the 2012 Russian Presidential Elections." Journal of Elections, Public Opinion and Parties 26(2): 191-211.

Kirdiş, Esen. 2016. "From Loyal to Hard Opposition: The Political Transformation of the Jordanian Muslim Brotherhood." Politics, Religion \& Ideology 17(2-3): 121-142

Kuran, Timur. 1997. Private Truths, Public Lies: The Social Consequences of Preference Falsification. Cambridge: Harvard University Press.

Lynch, Marc. 2006. "Anti-Americanisms in the Arab World." In Anti-Americanisms in World Politics, edited by Katzenstein Peter J. and Keohane Robert O, 196-224. New York: Cornell University Press.

Lynch, Marc. 2013. The Arab Uprising: The Unfinished Revolutions of the New Middle East. New York: Public Affairs.

Marinov, Nikolay. 2013. "Voter Attitudes when Democracy Promotion turns Partisan: Evidence from a Survey-experiment in Lebanon." Democratization 20(7): 1297-1321. 
Melman, Yossi. (2011). "Rebel Spokesman to Haaretz: Libya Needs World's Help, Including Israel's.” https://www.haaretz.com/1.5154663 24 August, 2011. (Accessed March 11, 2018).

Mortimer, Robert A. 2015. "Algerian Foreign Policy: From Revolution to National Interest." The Journal of North African Studies 20(3): 466-482.

Paoletti, Emanuela. 2011. "Migration and Foreign Policy: The Case of Libya." The Journal of North African Studies 16(2): 215-231.

Petrucci, Filippo, and Marisa Fois. 2016. “Attitudes towards Israel in Tunisian Political Debate: From Bourguiba to the New Constitution.” Journal of North African Studies 21(3): 392410.

Ryan, Curtis R. 2009. Inter-Arab Alliances: Regime Security and Jordanian Foreign Policy. Gainesville: University Press of Florida.

Segev, Samuel, and Yvette Shumacher. 2008. "Israel-Morocco Relations from Hassan II to Muhammad VI.” Israel Journal of Foreign Affairs 2(3): 49-60.

Shama, Nael M. 2014. Egyptian Foreign Policy from Mubarak to Morsi: Against the National Interest. New York: Routledge.

Solingen, Etel. 2012. "Of Dominoes and Firewalls: The Domestic, Regional, and Global Politics of International Diffusion." International Studies Quarterly 56(4): 631-644.

St John, Ronald Bruce. 2003. "Libyan Foreign Policy: Newfound Flexibility." Orbis 47(3): 463477.

Tannenberg, Marcus. 2017. "The Autocratic Trust Bias: Politically Sensitive Survey Items and Self-censorship." Working Paper 176. Afrobarometer. 
Tessler, Mark. 2016. “Carnegie Middle East Governance and Islam Dataset, 1988-2014.” Interuniversity Consortium for Political and Social Research. April 28, 2016.

Tessler, Mark A. 2009. A History of the Israeli-Palestinian Conflict. Bloomington, Indianapolis: Indiana University Press.

Tessler, Mark, and Michael Robbins. 2007. “What Leads some Ordinary Arab Men and Women to Approve of Terrorist Acts against the United States?” Journal of Conflict Resolution 51(2): 305-328.

Tessler, Mark, Amaney Jamal, and Michael Robbins. 2012. "New Findings on Arabs and Democracy.” Journal of Democracy 23(4): 89-103.

Tessler, Mark, and Ina Warriner, I 1997, “Gender, Feminism, and Attitudes toward International Conflict: Exploring Relationships with Survey Data from the Middle East.” World Politics 49(2): 250-281.

Transitional Governance Project. 2016. “Transitional Governance Project Home Page.” http://transitionalgovernanceproject.org/.

“The Tunisian Constitution of 2014.”

https://www.constituteproject.org/constitution/Tunisia_2014.pdf (Accessed March 16, 2017).

United Nations. (2011). “After Much Wrangling, General Assembly Seats National Transitional Council of Libya as Country's Representative for Sixty-Sixth Session.” http://www.un.org/press/en/2011/ga11137.doc.htm 16 September, 2011. (Accessed March 11, 2018). 
Waltz, Kenneth. 1975. "Theory of International Relations," in Handbook of Political Science: International Relations, vol.8, edited by Fred Greenstein and Nelson Polsby, 1-86. Boston: Addison-Wesley Publishing Company

Waltz, Kenneth. 1957. Man, the State, and War. New York: Columbia University Press.

Zoubir, Yahia H. and Louisa Ait-hamadouche. 2006. Anti-Americanism in North Africa: Could State Relations overcome Popular Resentment?" The Journal of North African Studies 11(1): 35-54. 
Table 1

Nationally-representative surveys in North Africa (pre- and post-Arab Spring)

\begin{tabular}{|c|c|c|c|c|c|c|c|c|c|c|c|}
\hline & \multicolumn{2}{|c|}{$\begin{array}{c}\text { World } \\
\text { Values } \\
\text { Survey }\end{array}$} & \multicolumn{2}{|c|}{$\begin{array}{c}\text { Arab } \\
\text { Barometer }\end{array}$} & \multicolumn{2}{|c|}{$\begin{array}{c}\text { Afro } \\
\text { Barometer }\end{array}$} & \multicolumn{2}{|c|}{$\begin{array}{c}\text { Transitional } \\
\text { Governance } \\
\text { Project }\end{array}$} & \multicolumn{2}{|c|}{$\begin{array}{l}\text { Program on } \\
\text { Governance } \\
\text { and Local } \\
\text { Development }\end{array}$} & \multirow[t]{2}{*}{$\begin{array}{c}\text { Total } \\
\text { surveys/country }\end{array}$} \\
\hline & $\begin{array}{l}\text { Pre- } \\
2011\end{array}$ & $\begin{array}{l}\text { Post- } \\
2011\end{array}$ & $\begin{array}{l}\text { Pre- } \\
2011\end{array}$ & $\begin{array}{l}\text { Post- } \\
2011\end{array}$ & $\begin{array}{l}\text { Pre- } \\
2011\end{array}$ & $\begin{array}{l}\text { Post- } \\
2011\end{array}$ & $\begin{array}{l}\text { Pre- } \\
2011\end{array}$ & $\begin{array}{l}\text { Post- } \\
2011\end{array}$ & $\begin{array}{l}\text { Pre- } \\
2011\end{array}$ & $\begin{array}{l}\text { Post- } \\
2011\end{array}$ & \\
\hline Morocco & $\begin{array}{l}2001 \\
2007\end{array}$ & 2011 & 2006 & $\begin{array}{l}2013- \\
2014 \\
2016\end{array}$ & - & 2013 & - & - & - & - & 7 \\
\hline Algeria & 2002 & 2013 & 2006 & $\begin{array}{l}2011 \\
2013 \\
2016 \\
\end{array}$ & - & 2013 & - & - & - & - & 7 \\
\hline Tunisia & - & 2013 & - & $\begin{array}{l}2011 \\
2013 \\
2016 \\
\end{array}$ & - & 2013 & - & $\begin{array}{l}2012 \\
2014\end{array}$ & - & 2015 & 8 \\
\hline Libya & - & 2014 & - & 2014 & - & 2013 & - & $\begin{array}{c}2013 \\
(3 \\
\text { surveys })\end{array}$ & - & - & 6 \\
\hline Egypt & $\begin{array}{l}2001 \\
2008\end{array}$ & 2013 & - & $\begin{array}{l}2011 \\
2013 \\
2016\end{array}$ & - & - & - & $\begin{array}{l}2011 \\
2012\end{array}$ & - & - & 8 \\
\hline $\begin{array}{l}\text { Sub- } \\
\text { total }\end{array}$ & 5 & 5 & 2 & 12 & 0 & 4 & 0 & 7 & 0 & 1 & \\
\hline Total & & 0 & & 4 & & 4 & & 7 & & & 36 \\
\hline
\end{tabular}


Table 2

Perception of most important problem facing the country (2006-08) (percentage identifying issue as the most important)

\begin{tabular}{|l|r|r|}
\hline & Algeria & Morocco \\
\hline Intemal issues & & \\
\hline Economic situation & $51 \%$ & $56 \%$ \\
\hline Corruption & $31 \%$ & $27 \%$ \\
\hline Authoritarianism & $8 \%$ & $4 \%$ \\
\hline & Algeria & Morocco \\
\hline External issues & & \\
\hline Ending U.S. occupation in Iraq & $1 \%$ & $1 \%$ \\
\hline Arab-Israeli conflict & $2 \%$ & $2 \%$ \\
\hline Other & & $7 \%$ \\
\hline Don't know/refuse & $8 \%$ & $4 \%$ \\
\hline
\end{tabular}

Source: Arab Barometer, Wave 1. Question not asked in Waves 2-4.

Question wording: "In your opinion which of the following is the most important problem facing [respondent's country] today? Economic situation (poverty, unemployment, inflation);

Corruption; Authoritarianism; Ending the U.S. occupation of Iraq; The Arab-Israeli conflict.” 
Table 3

Perceived causes of the Arab Spring (2011) (percentage identifying a cause)

\begin{tabular}{|l|c|c|}
\hline & Egypt & Tunisia \\
\hline Internal issues & & \\
\hline Economic situation & $54 \%$ & $63 \%$ \\
\hline Civil freedoms & $7 \%$ & $14 \%$ \\
\hline Prevent Gamal Mubarak from taking power & $7 \%$ & \\
\hline Corruption & $29 \%$ & $17 \%$ \\
\hline Replace Mubarak/Ben Ali & $10 \%$ & $4 \%$ \\
\hline Social justice & $0 \%$ & $0 \%$ \\
\hline Price hikes & $0 \%$ & $0 \%$ \\
\hline Extemal issues & & \\
\hline Pro-Western policy & $1 \%$ & $0 \%$ \\
\hline Pro-Israeli policy & $0 \%$ & $0 \%$ \\
\hline Don't know/refuse & $1 \%$ & $2 \%$ \\
\hline
\end{tabular}

Source: Arab Barometer, Wave 2. Question not asked in Wave 3.

Question wording: "A number of citizens participated in the protests between 25 January and 11 February 2011 for various reasons. In your opinion, what was the most important and the second most important reason for the protests? Demands for improving the economic situation; Demands for civil and political freedoms and liberation from repression; Demands for authority not to be passed down to Gamal Mubarak; Combating corruption; Replacing the Mubarak regime with an Islamic regime; Objecting to pro-Western Egyptian policy; Objecting to proIsrael Egyptian policy." Tunisia: “A number of citizens participated in the protests between 17 December 2010 and 14 January 2011 for various reasons. In your opinion, what was the most important and the second most important reason for the protests? Demands for improving the economic situation; Demands for civil and political freedoms and liberation from repression; Combating corruption; Replacing Ben Ali's regime with an Islamic regime; Objecting to proWestern Tunisian policy; Other.” 


\section{Figure 1}

Perception of extemal vs. intemal sources for the lack of development (2007-16) (percentage indicating extemal vs. intemal sources)

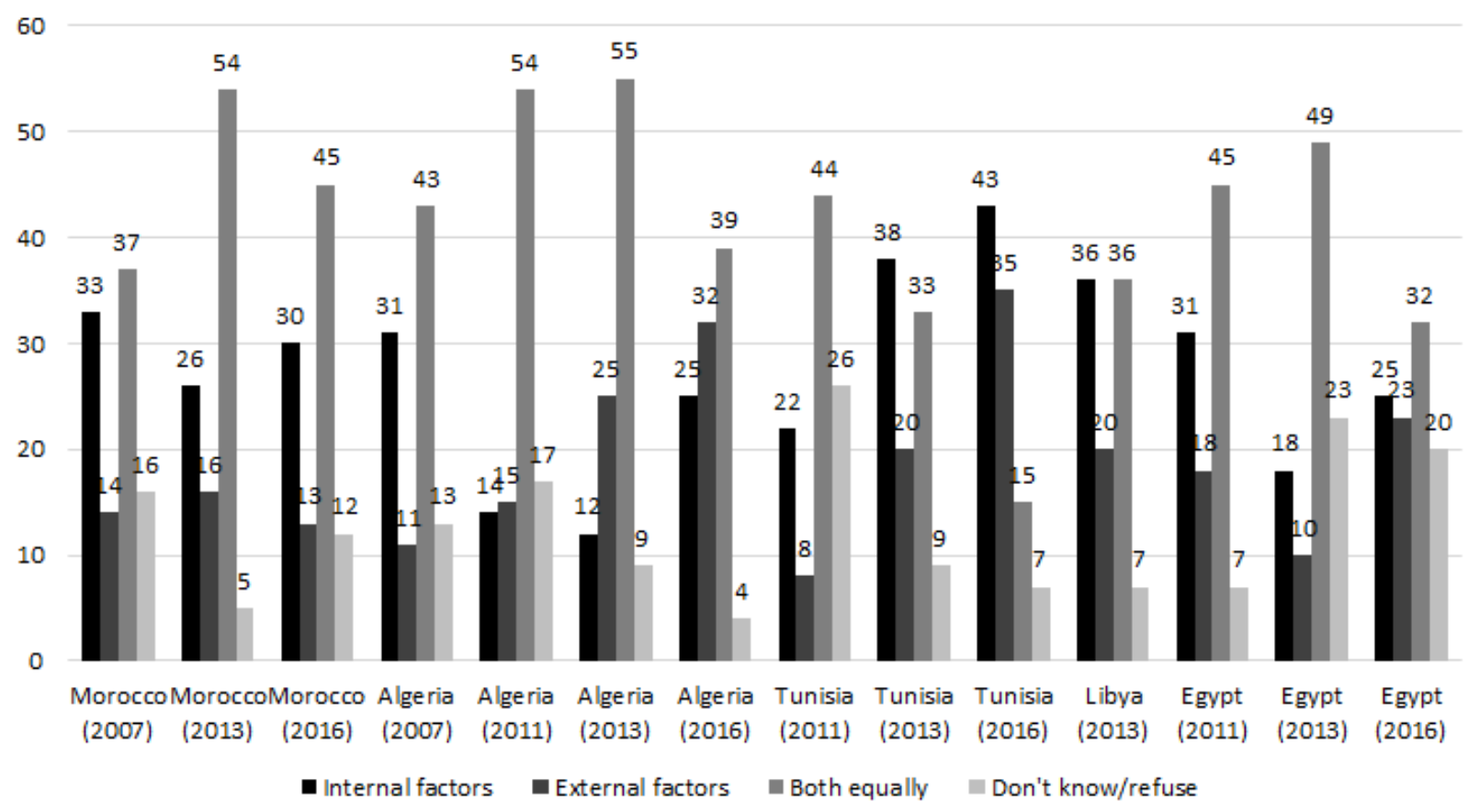

Source: Arab Barometer, Wave 4.

Question wording: "Some people attribute the lack of development in the Arab world compared to other parts of the world to external factors, while others blame internal factors. In your opinion, which is more important in causing the lack of development in the Arab world? 1. Internal factors. 2. External factors. 3. Both are equally important (Do not read).” 


\section{Figure 2}

Perception of foreign interference as an obstacle to reform in North Africa (2011-16) (percentage agreeing to some or a great extent)

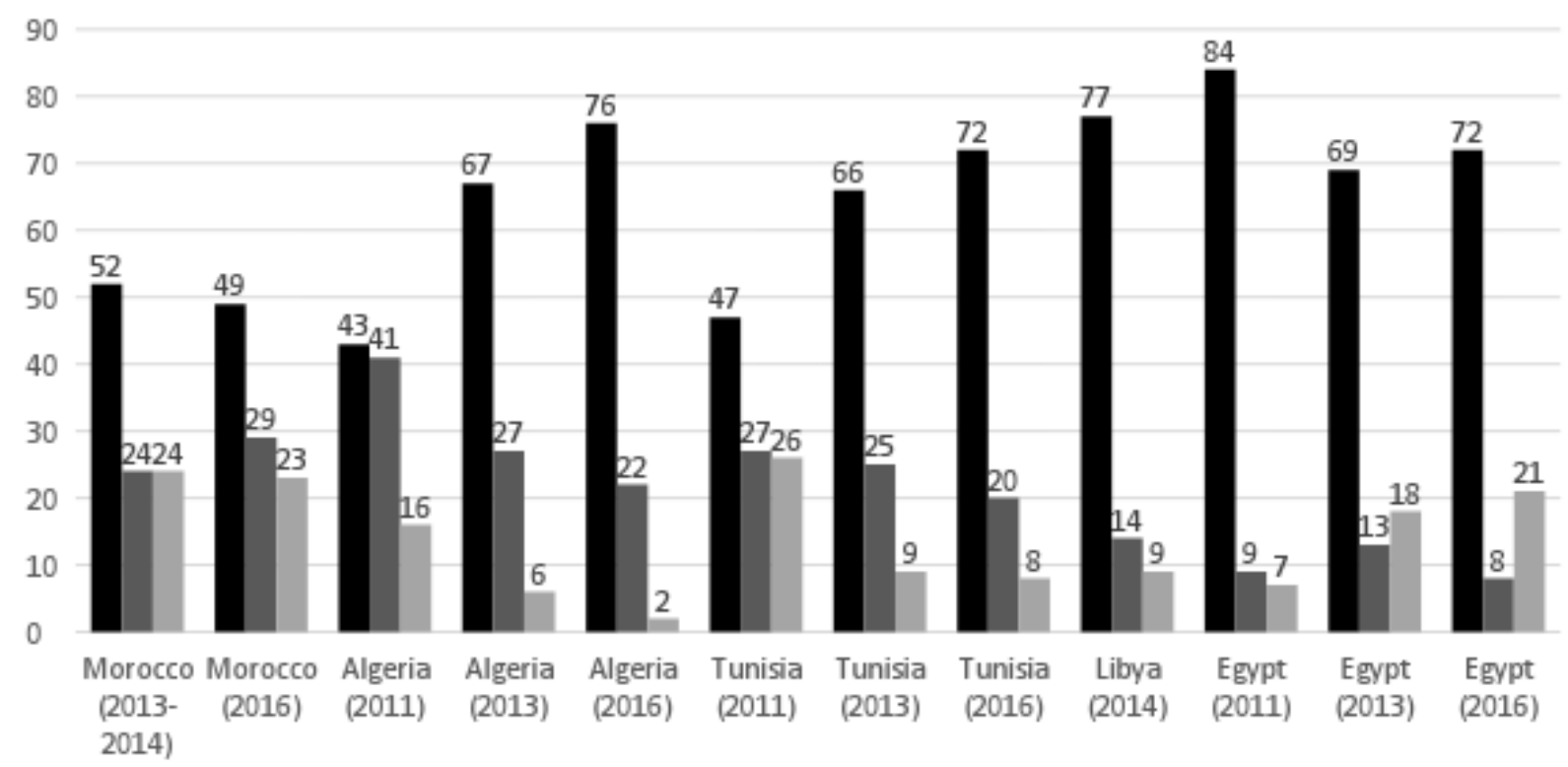

Agree to some or a great extent Disagree to some extent or absolutely Don't know/refuse

Source: Arab Barometer, Waves 2-4. Question not asked in Wave 1.

Question wording: "To what extent do you agree or disagree with the following statements:

Foreign interference is an obstacle to reform in your country. I agree to a great extent; I agree to some extent; I disagree; I absolutely disagree.” 
Figure 3

Public opinion attitudes about recognising Israel (Waves 1-3) (percentage)

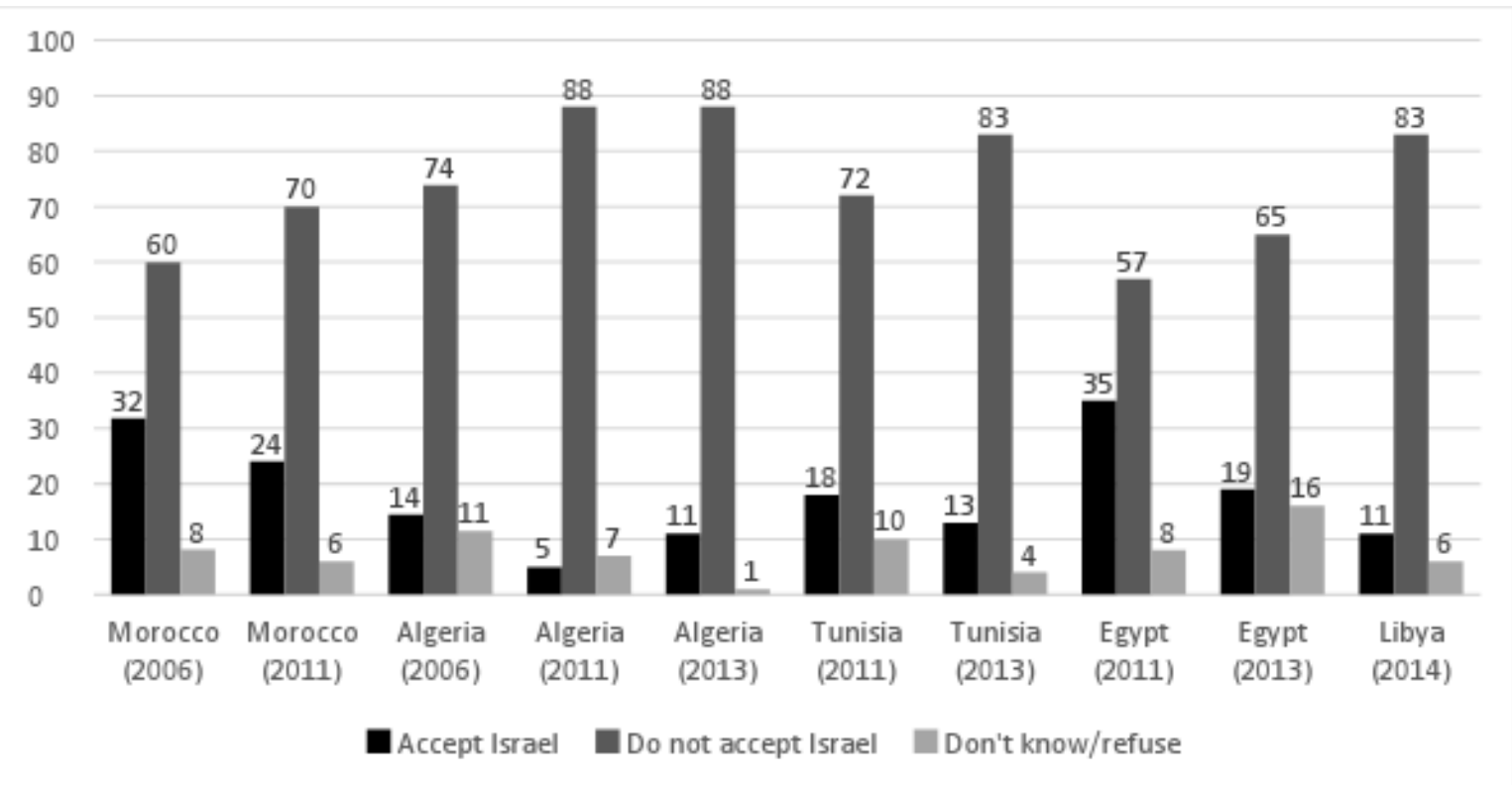

Source: Arab Barometer, Wave 1-3.

Question wording: "Which of the following statements best expresses your opinion about the problem of Israel and Palestine? The Arab world should accept the existence of Israel as a Jewish state in the Middle East only when the...; The Arab world should not accept the existence of Israel as a Jewish state in the Middle East.” This question was not asked in the $4^{\text {th }}$ Wave. 


\section{Figure 4}

Public opinion attitudes about recognising Israel (Wave 4) (percentage)

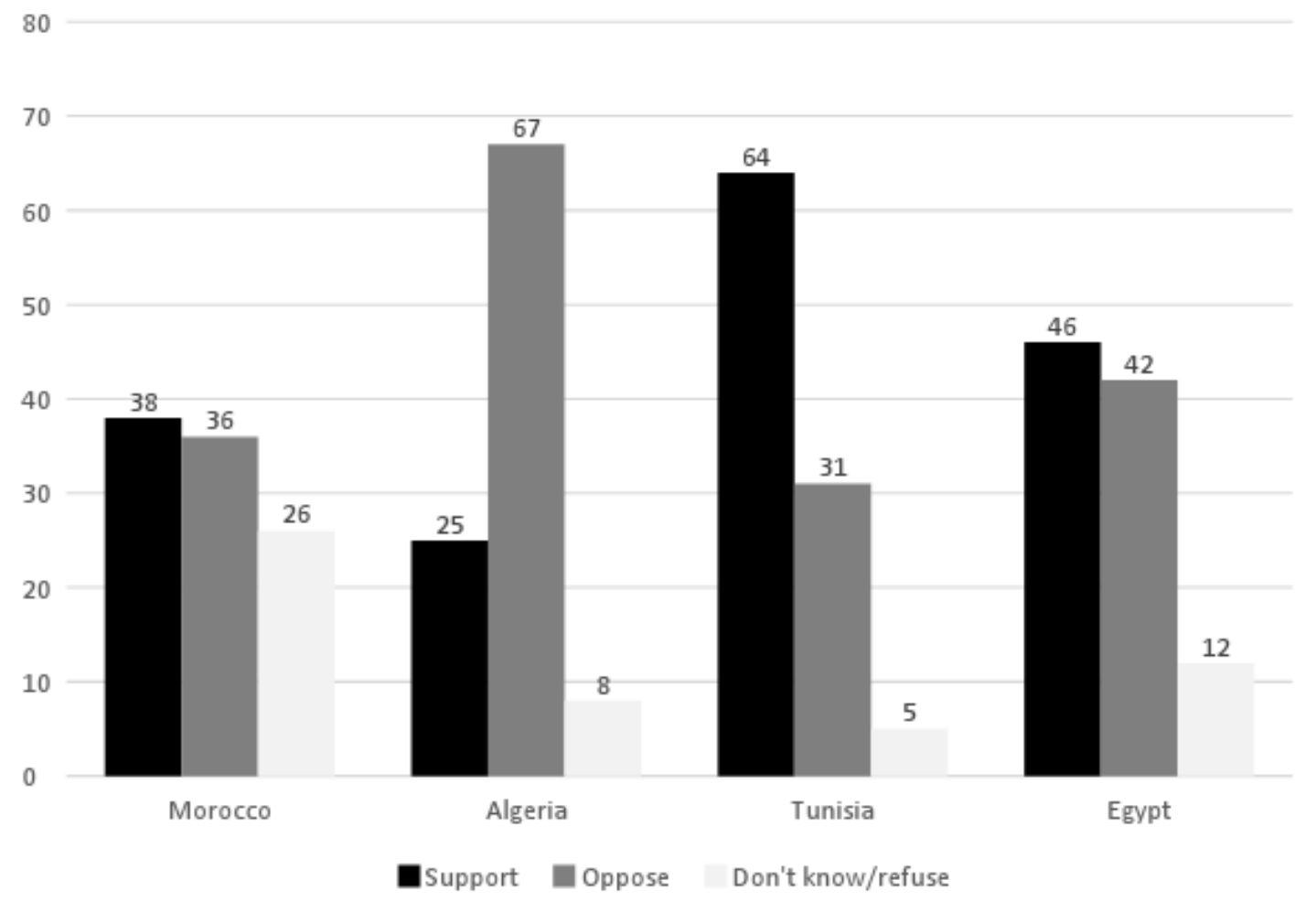

Source: Arab Barometer, Wave 4.

Question wording: "Do you support or oppose the solution to the Arab-Israeli conflict based on the establishment of a Palestinian State alongside Israel known as the two-state solution? 1. Support. 2. Oppose.” 


\section{Figure 5}

\section{Egyptian public opinion attitudes about existing peace treaty with Israel (percentage)}

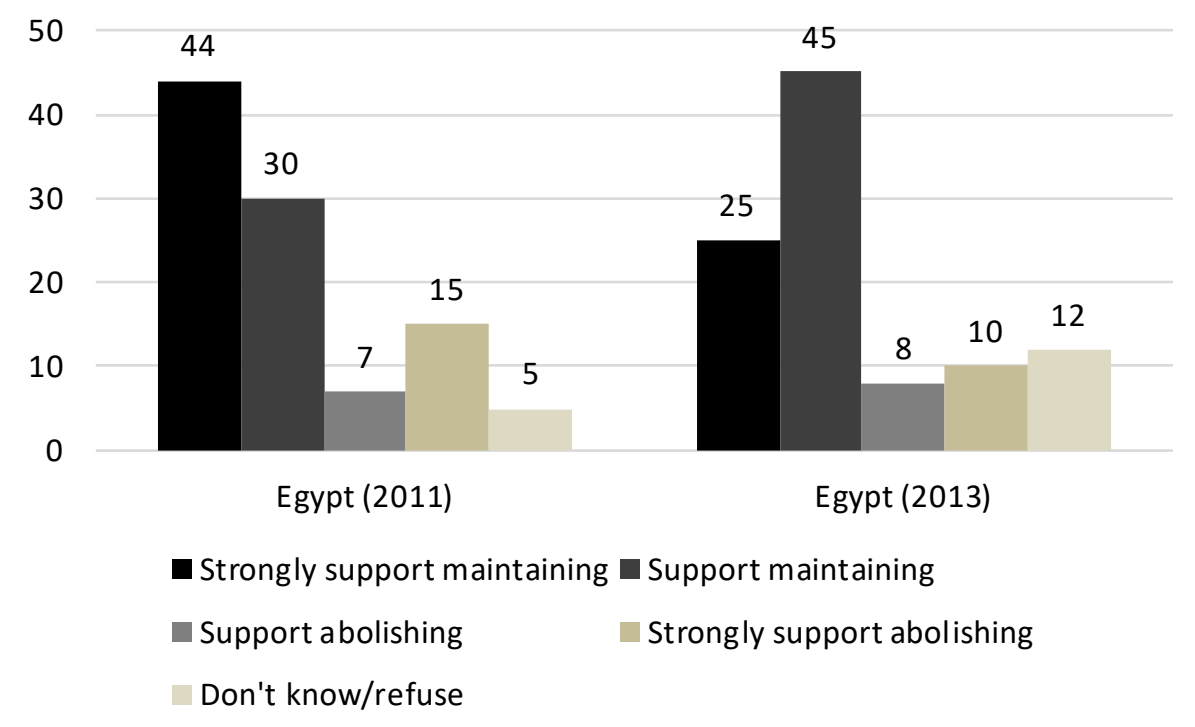

Source: Arab Barometer, Wave 3. Question not asked in Wave 4.

Question wording: "Do you: Strongly support maintaining the peace treaty with Israel; Support maintaining the peace treaty with Israel; Support abolishing the peace treaty with Israel; Strongly support abolishing the peace treaty with Israel.” 
Figure 6

Public opinion attitudes about economic relations with Israel (percentage)

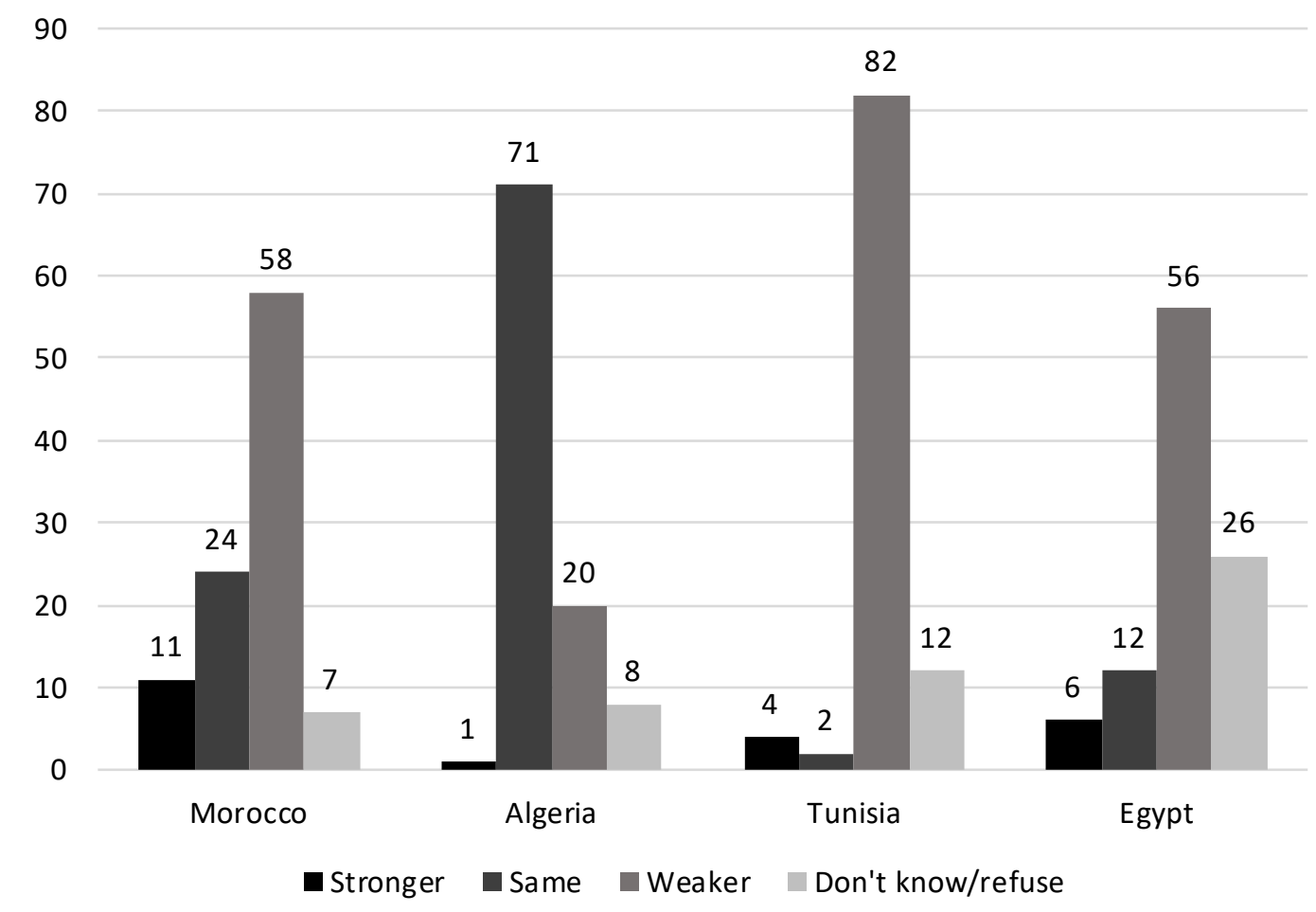

Source: Arab Barometer, Wave 3.

Question wording: "Do you prefer that future economic relations between your country and Israel. Become stronger than they were in previous years; Remain the same as they were in previous years; Become weaker than they were in previous years.” 


\section{Figure 7}

Public opinion attitudes about security relations with Israel (percentage)

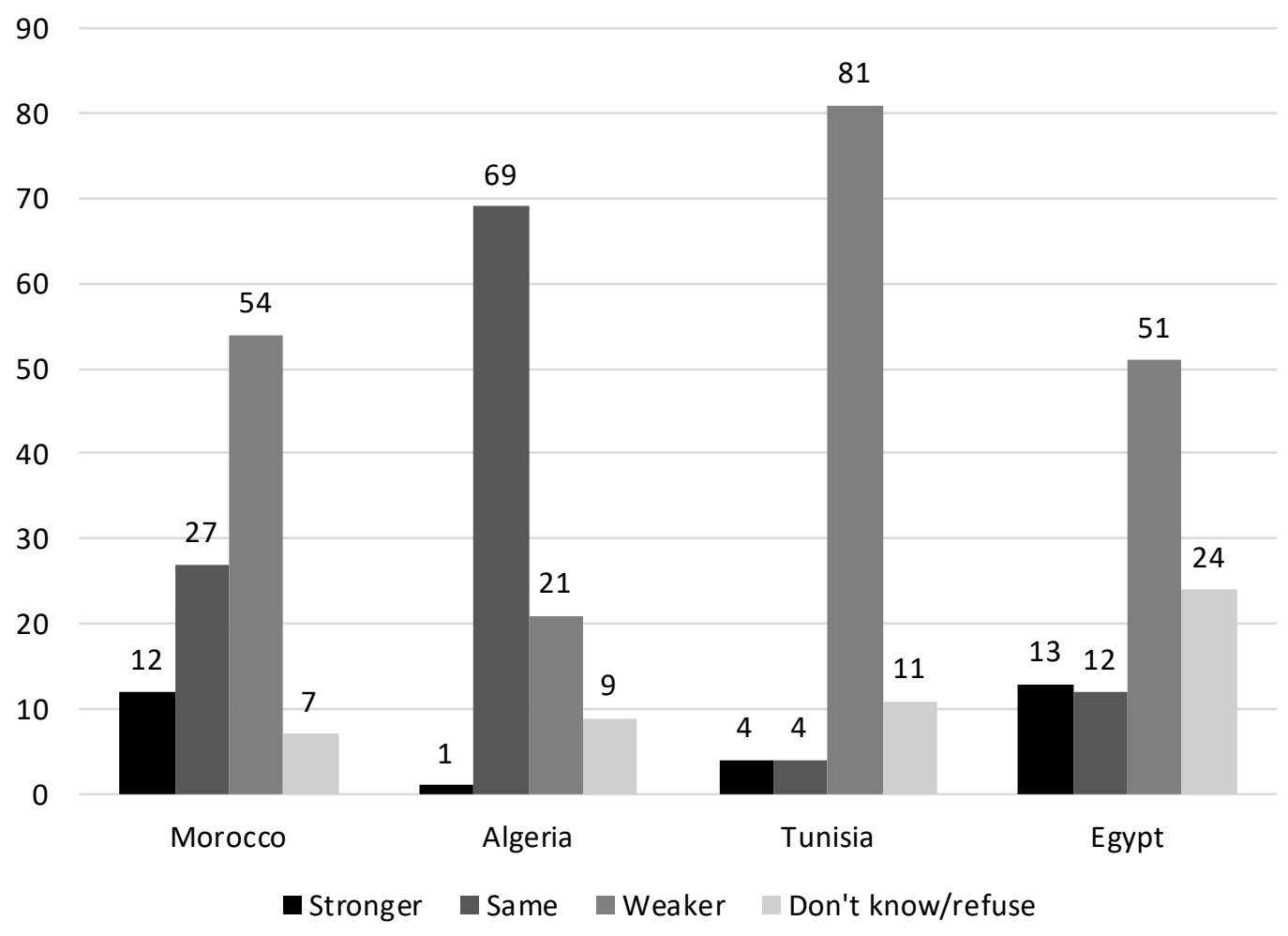

Source: Arab Barometer, Wave 3.

Question wording: "Do you prefer that future security relations between your country and Israel. Become stronger than they were in previous years; Remain the same as they were in previous years; Become weaker than they were in previous years.” 


\section{Figure 8}

Public opinion attitudes about American and Western culture (percentage)

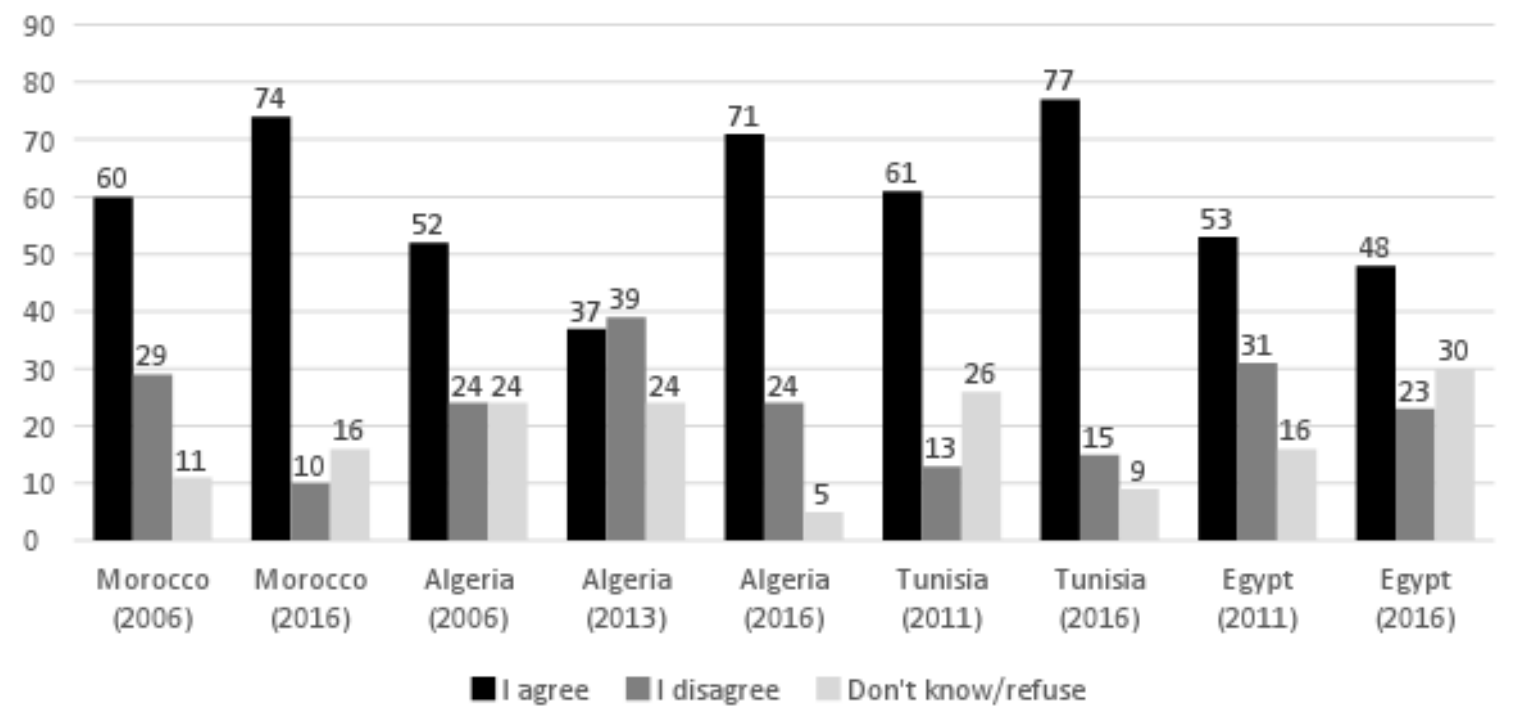

Source: Arab Barometer, Waves 1-2 and 4. Question not asked in Wave 3.

Question wording: "Do you agree or disagree with the following statement: American and Western culture have positive aspects. I strongly agree; I disagree.” (Wave 1-2). "Do you agree or disagree with the following statement: American and Western culture have positive aspects? 1. Strongly agree 2. Agree 3. Disagree 4. Strongly disagree.” (Wave 4). 


\section{Table 4}

Public opinion attitudes regarding desired U.S. policy approach to the Arab world (percentage)

\begin{tabular}{|c|c|c|c|c|c|c|c|c|c|}
\hline & $\begin{array}{l}\text { Algeria } \\
(2013)\end{array}$ & $\begin{array}{l}\text { Algeria } \\
(2016)\end{array}$ & $\begin{array}{l}\text { Egypt } \\
\text { (2013) }\end{array}$ & $\begin{array}{l}\text { Egypt } \\
\text { (2016) }\end{array}$ & $\begin{array}{l}\text { Libya } \\
\text { (2014) }\end{array}$ & $\begin{array}{c}\text { Morocco } \\
(2014)\end{array}$ & $\begin{array}{c}\text { Morocco } \\
\text { (2016) }\end{array}$ & $\begin{array}{l}\text { Tunisia } \\
\text { (2013) }\end{array}$ & $\begin{array}{l}\text { Tunisia } \\
\text { (2016) }\end{array}$ \\
\hline $\begin{array}{c}\text { Promote } \\
\text { democracy }\end{array}$ & $1 \%$ & $9 \%$ & $10 \%$ & $4 \%$ & $11 \%$ & $13 \%$ & $7 \%$ & $8 \%$ & $4 \%$ \\
\hline $\begin{array}{c}\text { Promote } \\
\text { economic } \\
\text { development }\end{array}$ & $3 \%$ & $11 \%$ & $7 \%$ & $7 \%$ & $12 \%$ & $25 \%$ & $18 \%$ & $26 \%$ & $19 \%$ \\
\hline Contain Iran & $1 \%$ & & $1 \%$ & & $2 \%$ & $3 \%$ & & $0 \%$ & \\
\hline $\begin{array}{l}\text { Solve the Arab- } \\
\text { Israeli conflict }\end{array}$ & $7 \%$ & $23 \%$ & $15 \%$ & $15 \%$ & $11 \%$ & $20 \%$ & $27 \%$ & $7 \%$ & $19 \%$ \\
\hline $\begin{array}{c}\text { Promote women's } \\
\text { rights }\end{array}$ & $1 \%$ & $8 \%$ & $1 \%$ & $2 \%$ & $1 \%$ & $5 \%$ & $4 \%$ & $1 \%$ & $3 \%$ \\
\hline $\begin{array}{c}\text { The U.S. should } \\
\text { not interfere }\end{array}$ & $79 \%$ & $44 \%$ & $44 \%$ & $62 \%$ & $54 \%$ & $26 \%$ & $31 \%$ & $54 \%$ & $50 \%$ \\
\hline Don't know/refuse & $8 \%$ & $5 \%$ & $25 \%$ & $10 \%$ & $9 \%$ & $8 \%$ & $13 \%$ & $4 \%$ & $5 \%$ \\
\hline
\end{tabular}

Source: Arab Barometer, Waves 3-4. Question not asked in Waves 1-2.

Question wording: "What is the most positive policy that the U.S. can follow in our region? Promote democracy; Promote economic development; Contain Iran; Solve the Arab-Israeli Conflict; Promote women's rights; The U.S. shouldn't interfere.” 


\section{Figure 9}

Public opinion regarding support for armed operations against the U.S. (percentage)

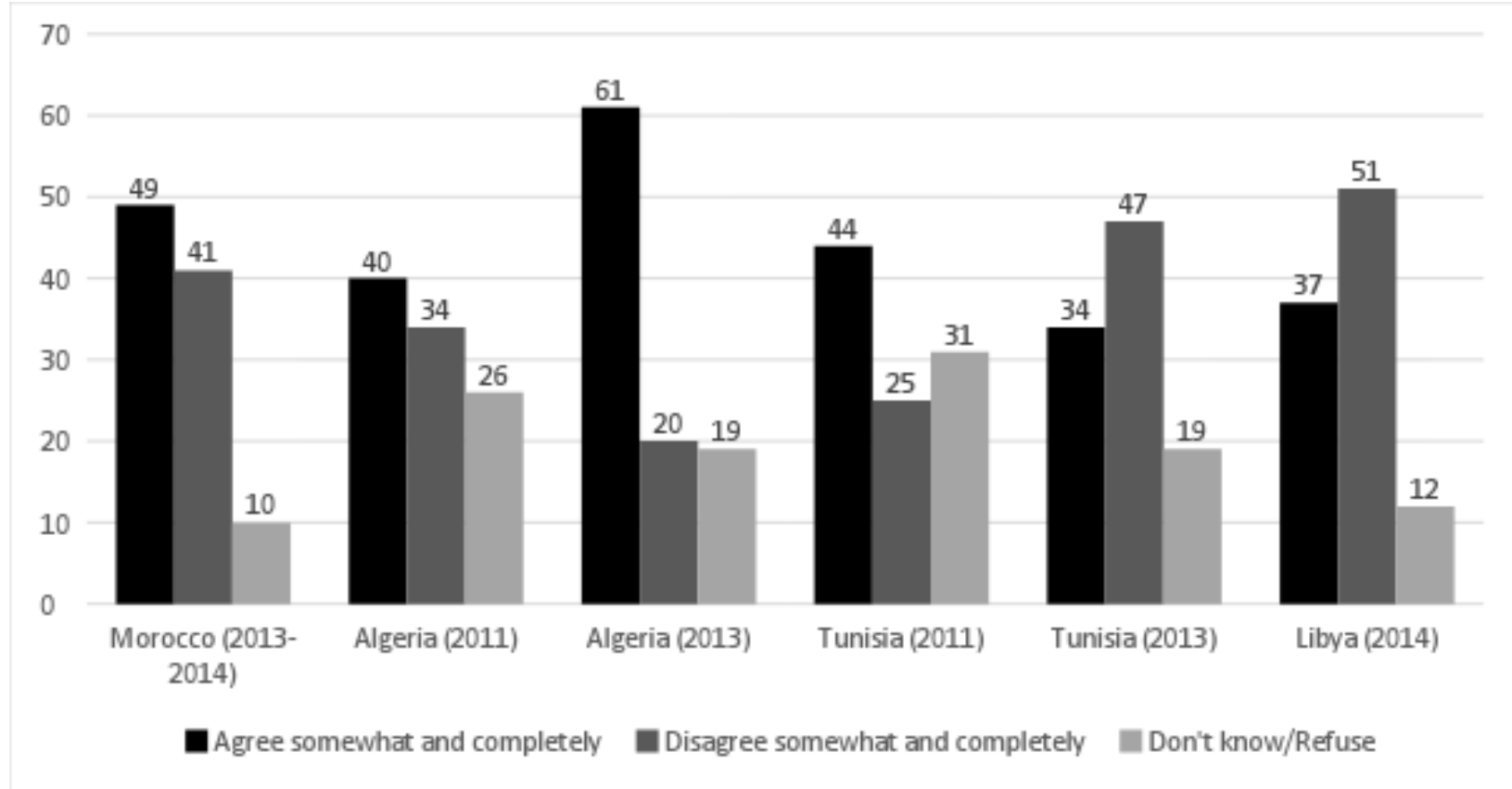

Source: Arab Barometer, Waves 2-3. Question not asked in Waves 1 or 4.

Question wording: 'Do you agree or disagree with the following statement: The United States' interference in the region justifies armed operations against the United States everywhere. I strongly agree; I agree; I disagree; I strongly disagree.” 